\title{
Pengembangan Pembelajaran Pendidikan Agama Islam Sekolah Adiwiyata dalam Menghadapi Era Revolusi Industri 4.0: Studi di SMA Negeri 1 Lamongan
}

Moh. Irmawan Jauhari

STAI-Ma'arif Kendal Ngawi

irmawanj@gmail.com

\section{Article History:}

Received: 09-02-2019

Revised: 15-02-2019

Accepted: 10-03-2019

\begin{abstract}
Issues concerning the environment and the industrial revolution must be considered in the world of education. Educational institutions must not be absent, let alone be ignorant of the trends of the times which are continually changing from time to time. For this reason, schools need to pay attention to the provision of education that can help students not stutter in dealing with environmental issues and the rapid development of information technology. This study aims to find out about 1) How the development of adiwiyata PAI learning in the face of the industrial revolution 4.0 era in SMA Negeri 1 Lamongan, 2) How are the supporting and inhibiting factors in the development of PAI learning in adiwiyata schools in the face of the industrial revolution 4.0 era at SMA Negeri 1 Lamongan, 3) How to overcome the inhibiting factors of PAI adiwiyata school learning development in the face of the industrial revolution 4.0 era in SMA Negeri 1 Lamongan, research using this qualitative method successfully concluded, among others: 1) learning conditions, including learning objectives, characteristics of the field of study, constraints learning, student characteristics. 2) Learning methods, including organizing strategies, delivery strategies, management strategies. 3) PAI learning outcomes, including effectiveness, efficiency, learning attractiveness. Supporting and inhibiting factors encountered in the development of PAI learning in the era of the industrial revolution 4.0 is from the educational background of students, extracurricular activities, habituation of school religious programs, infrastructure, student interest, family, and relationships. And how to overcome these inhibiting factors is to provide guidance and direction, provide motivation, and collaborate between students, teachers, and parents.
\end{abstract}

Keyword: Islamic Learning education, enviromental care, indrustial revolution

\section{Pendahuluan}

Pendidikan memegang peranan penting dalam memajukan suatu bangsa dengan berkembangnya zaman, tantangan dan hambatan pendidikan Islam juga terus mengalami perkembangan dan perubahan yang sangat cepat, berdasarkan hal tersebut pendidikan dituntut untuk bisa meningkatkan dan mengembangkan kualitas proses pembelajaran agar mampu menghasilkan generasi yang berkualitas dan kritis dalam menghadapi tantangan maupun perubahan-perubahan yang terjadi pada zaman sekarang. Sebagaimana firman Allah dalam Al-Qur'an Surat Ali Imran : 190 


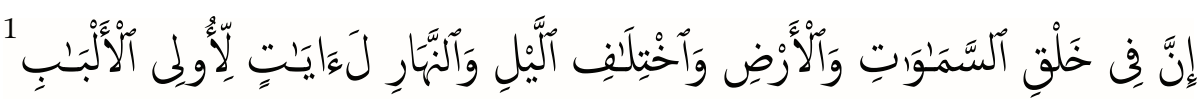

Sesungguhnya dalam penciptaan langit dan bumi, dan pergantian malam dan siang terdapat tanda-tanda (kebesaran Allah) bagi orang yang berakal"2

Dalam ayat di atas, menjelaskan bahwa dengan potensi ilmu yang dianugerahkan pada manusia diharapkan manusia mampu menangkap peluang dan tantangan di era globalisasi ini dengan keahlian-keahlian yang dimiliki. Dan tantangan bagi dunia pendidikan di zaman sekarang adalah bagaimana menciptakan sumber daya manusia atau peserta didik yang mampu bertahan dan berkembang dalam era serba inovatif dan kreatif.

Begitu juga posisi lembaga pendidikan Islam sebagai agen peradaban dan perubahan sosial yang diharapkan mampu memberikan kontribusi dan perubahan positif pada perbaikan dan kemajuan peradaban umat islam. ${ }^{3}$ Keberadaan pendidikan islam sangat penting sebagai suatu upaya atau proses, pencarian, pembentukan, dan pengembangan sikap dan perilaku untuk mencari, mengembangkan, memelihara, serta menggunakan ilmu dan perangkat teknologi atau keterampilan demi kepentingan sesuai dengan ajaran Islam. ${ }^{4}$

Pengembangan pada pembelajaran Pendidikan Agama Islam di sekolah sangat dibutuhkan terutama di sekolah yang sudah mendapatkan program adiwiyata yang dapat digunakan untuk meningkatkan kualitas pembelajaran bagi peserta didik. Karena sekolah adiwiyata sebagai tempat yang baik dan ideal di mana dapat diperoleh segala ilmu pengetahuan dan berbagai norma serta etika yang dapat menjadi dasar manusia menuju terciptanya kesejahteraan hidup kita dan menuju kepada cita-cita pembangunan berkelanjutan. Program Adiwiyata mempunyai tujuan mewujudkan warga sekolah yang bertanggung jawab dalam upaya perlindungan dan pengelolaan lingkungan hidup melalui tata kelola sekolah yang baik untuk mendukung pembangunan berkelanjutan. ${ }^{5}$

Sekolah adiwiyata harus mempunyai inovasi dalam meningkatkan kualitas pendidikan dalam menghadapi kemajuan Era Revolusi Industri 4.0 dimana Era ini mengubah cara manusia hidup, bekerja, dan berkomunikasi yang ditandai dengan munculnya terobosan teknologi disejumlah bidang, termasuk robotika, kecerdasan buatan, nanoteknologi, komputasi kuantum, bioteknologi, Internet of Things (IoT), pencetakan 3D, dan kendaraan otonom (autonomous vehicles). ${ }^{6}$

Era Revolusi Industri 4.0 ditandai dengan semakin sentralnya peran teknologi cyber dalam kehidupan manusia dan membawa dampak yang tidak sederhana. Ia

\footnotetext{
3 Mukammad Ilyasin dan Nanik Nur Hayati, Manajemen Pendidikan Islam (Yogyakarta : Aditya Media Publishing, 2012), 4.

${ }^{4}$ Baharuddin, Pendidikan dan Psikologi Perkembangan, (Yogyakarta : Ar-Ruzz Media, 2017), 197.

${ }^{5}$ Hayyan Ahmad Ulul Albab, "Memahami PAI melalui Program Adiwiyata (Cinta Lingkungan) di SMPN 2 Lamongan”. Jurnal JALIE, Vol.1, No.2, (September, 2017), 259.

${ }^{6}$ Astrid Safitri, Revolusi Industri 4.0 : Mengubah Tantangan Menjadi Peluang di Era Disrupsi 4.0 (Yogyakarta : Penerbit Genesis, 2019), 63.
} 2004), 75 .

${ }^{1}$ Al Qur'an, $3: 190$.

2 Departemen Agama RI, Al-Qur'an dan Terjemahnya (Bandung: CV Penerbit Jumanatul Ali-Art, 
berdampak pada seluruh aspek kehidupan manusia baik di bidang ekonomi, politik, kebudayaan, seni, bahkan sampai ke dunia pendidikan. ${ }^{7}$ Dalam dunia pendidikan Era Revolusi Industri 4.0 merupakan tantangan yang sangat besar oleh karena itu lembaga pendidikan memerlukan upaya untuk membentuk mental manusia yang tangguh, berakhlakul karimah, cerdas, tahan uji, siap berkompetitif, sehingga siap dalam menghadapi tantangan di Era Revolusi Industri 4.0.8

SMA Negeri 1 Lamongan merupakan salah satu lembaga sekolah favorit di Lamongan dan sebagai sekolah pelopor adiwiyata di Lamongan yang sudah mendapat penghargaan sekolah adiwiyata mandiri sejak tahun 2011. Pengembangan pembelajaran Pendidikan Agama Islam pada program adiwiyata di SMA Negeri 1 Lamongan biasanya dimasukkan ke dalam RPP dan kemudian harus diinkrut ke kurikulum.

Dalam mengadapi Era Revolusi Industri 4.0 semua guru terutama guru SMA Negeri 1 Lamongan berupaya meningkatkan kualitas pembelajaran pendidikan agama Islam dan dapat mengembangkan pembelajaran agama Islam yang lebih maju lagi dengan meningkatkan dan mengembangkan kurikulum pembelajaran, metode pembelajaran, maupun media pembelajaran yang digunakan di sekolah tersebut sesuai dengan perkembangan zaman. Karena di Era Revolusi Industri 4.0 guru bukan lagi sebagai central dalam pembelajaran, namun berubah menjadi fasilitator bagi penyediaan kebutuhan belajar peserta didik. ${ }^{9}$

Untuk itulah penulis hendak melakukan penelitian dengan judul "Pengembangan Pembelajaran PAI Sekolah Adiwiyata dalam Menghadapi Era Revolusi Industri 4.0 : Studi di SMA Negeri 1 Lamongan"

Penelitian ini menggunakan metode kualitatif dan pendekatan yang digunakan adalah pendekatan deskriptif, adapun alasan penelitian ini menggunakan pendekatan deskriptif karena dalam penelitian ini data yang dihasilkan berupa data deskriptif atau uraian dan bukan berupa angka-angka. Peneliti mengambil subyek penelitian di SMA Negeri 1 Lamongan yaitu guru PAI serta siswa SMA Negeri 1 Lamongan. Dengan teknik pengumpulan data wawancara, observasi, serta dokumentasi. Dan teknis analisis data menggunakan reduksi data, penyajian data, dan verifikasi data.

\section{Pengembangan Pembelajaran PAI Sekolah Adiwiyata dalam Menghadapi Era Revolusi Industri}

Pengembangan pembelajaran PAI yang dilakukan guru PAI dalam menghadapi era revolusi industri 4.0 di SMA Negeri 1 Lamongan adalah dengan memperhatikan komponen-komponen yang mempengaruhinya, yaitu:

1. Kondisi Pembelajaran PAI

${ }^{7}$ Afiful Hair, "Pendidikan Islam dalam Fenomena Disruption 4.0", Jurnal Pemikiran, Pendidikan, dan Penelitian Keislaman, Vol.05, No.2 (Juli, 2019), 1.

${ }^{8}$ Ida Widaningsih, Strategi dan Inovasi Pembelajaran Baasa Indonesia di Era Revolusi Industri 4.0, 5.

9 Afiful Hair, Pendidikan Islam dalam Fenomena Disruption 4.0, 1. 
Kondisi pembelajaran PAI adalah semua faktor yang mempengaruhi penggunaan metode pembelajaran PAI, yaitu tujuan pembelajaran PAI, karakteristik bidang studi PAI, kendala pembelajaran, dan karakteristik peserta didik. ${ }^{10}$

\section{a. Tujuan Pembelajaran PAI}

Tujuan Pembelajaran PAI di SMA Negeri 1 Lamongan secara umum sesuai dengan perundang-undangan tentang tujuan pendidikan nasional yang tercantum pada Undang-undang No 20 tahun 2003 tentang pendidikan nasional yang bertujuan untuk mengembangkan kemampuan dan membentuk watak serta peradaban bangsa yang bermartabat dalam rangka mencerdaskan kehidupan bangsa, bertujuan untuk mengembangkan potensi peserta didik agar menjadi manusia yang beriman, bertaqwa kepada Tuhan yang Maha Esa, berakhlak mulia, sehat, berilmu, cakap, kreatif, mandiri, dan menjadi warga Negara yang demokratis serta bertanggung jawab.

Selain tujuan pembelajaran PAI berdasarkan tujuan pendidikan nasional di atas, tujuan pembelajaran PAI yang ingin dicapai oleh guru PAI di SMA Negeri 1 Lamongan juga didasarkan pada aspek Kognitif (pengetahuan), Afektif (sikap), dan Psikomotorik (keterampilan) siswa yang bertujuan untuk menggali segala potensi maupun kemampuan siswa dalam mempelajari pembelajaran PAI. Dalam proses pembelajaran di era revolusi industri 4.0 ini guru PAI di SMA Negeri 1 Lamongan menyesuaikan tujuan pembelajaran PAI dengan perkembangan zaman dan kondisi siswa. Dalam memberikan pengetahuan dan keterampilan-keterampilan kepada siswa guru PAI melatih siswa untuk bisa berfikir kritis dan mampu berinovasi dalam memahami materi pembelajaran agar bisa mencapai tujuan pembelajaran yang diinginakan yang sesuai dengan tujuan pendidikan nasional, dan guru dapat mendorong siswa menjadi generasi yang siap diterjunkan ke dunia global yang penuh tantangan dan mampu memiliki kepribadian yang baik dan dapat mengaplikasikan ilmu yang diperoleh di kehidupan sehari-hari sesuai dengan perkembangan zaman.

b. Karakteristik Bidang Studi PAI

Karakteristik bidang studi PAI di SMA Negei 1 Lamongan mengacu pada pembelajaran PAI dan Budi pekerti yang di dalamnya memuat pembelajaran yang berkaitan dengan Al Qur'an/Hadist, Akidah/Akhlak, Fiqih, dan Sejarah kebudayaan Islam dengan menyesuaikan kurikulum yang digunakan yaitu menggunakan kurikulum K13.

Guru PAI di SMA Negeri 1 Lamongan dalam mengembangkan kurikulum juga memperhatikan pengembangan di era revolusi industri 4.0. dalam sistem pembelajaran di era revolusi industri 4.0 kurikulum yang dikembangkan oleh guru PAI di SMA Negeri 1 Lamongan menekankan pembelajaran yang berpusat pada peserta didik bukan pada pendidik lagi seperti halnya dalam kurikulum K13 pembelajaran yang diterapkan bertujuan untuk melatih siswa mampu berkomunikasi, bekerjasama, berpikir kritis dan mampu memecahkan masalah yang

\footnotetext{
${ }^{10}$ Muhaimin, Paradigma Pendidikan Islam: Upaya Mengefektifkan Pendidikan Agama Islam di Sekolah (Bandung: PT Remaja Rosdakarya, 2008), 150.
} 
dihadapi, dan mempunyai daya cipta dan inovasi. Semua hal tersebut sangat penting diterapkan kepada peserta didik untuk menjadi lulusan yang berkualitas dan dapat mengikuti dan mengubah zaman menjadi lebih baik.

Karakteristik bidang studi yang diterapkan guru PAI di SMA Negeri 1 Lamongan selain mengacu pada kurikulum K13 juga mengarah kepada pendidikan karakter. Guru PAI di SMA Negeri 1 Lamongan menerapkan pendidikan karakter untuk membimbing siswa mampu memiliki karakter dan moral yang baik untuk digunakan di kehidupan sehari-hari yang berguna untuk dirinya dan sekitarnya, terutama di era digitalisasi sudah di depan mata dan tidak bisa dihindari pendidikan karakter sangat penting untuk siswa agar tidak menyalahgunakan teknologi dan mampu menjadi generasi yang tidak hanya cerdas dalam ilmu pengetahuan dan teknologi, namun juga santun dan cerdas dalam perilaku.

c. Kendala Pembelajaran

Kendala pembelajaran PAI di SMA Negeri 1 Lamongan kebanyakan terletak pada diri siswa sendiri. Hal ini dikarenakan siswa kesulitan dalam mempelajarai ayat-ayat Al Qur'an baik dalam membaca, memahami, dan mengaplikasikannya dalam kehidupan sehari-hari, adanya problem keluarga, malas, dan susah dalam menerima materi pembelajaran.

Berdasarkan hal tersebut guru PAI di SMA Negeri 1 Lamongan memiliki cara dalam mengatasi kendala tersebut yaitu dengan memberikan nasihat, motivasi, bimbingan, dan melakukan kerja sama antara guru, siswa, dan orang tua yang bertujuan untuk menumbuhkan minat siswa dalam mengikuti dan mempelajari pembelajaran PAI dengan baik. Dan guru di SMA Negeri 1 Lamongan untuk menjadi guru yang mampu berkreasi, berinovasi, dan mengikuti perkembangan pendidikan di era revolusi industri 4.0 memiliki cara dengan mengikuti workshop, seminar, dan pelatihanpelatihan yang bertujuan untuk menunjang keberhasilan dalam memberikan materi pembelajaran, seperti mampu menghadapi Kendala dalam pembelajaran, mampu menjadi pendidik yang berkualitas, mampu memberikan materi yang up to date, mampu mengelola pembelajaran dengan baik, dan mampu mencetak siswa yang berkualitas dan siap dalam menghadapi tantangan zaman.

d. Karakteristik Peserta Didik

Karakteristik peserta didik di SMA Negeri 1 Lamongan bermacam-macam, hal ini dibuktikan dengan banyaknya jumlah siswa di SMA Negeri 1 Lamongan dengan total 1274. Dengan besarnya jumlah siswa tersebut maka semakin besar pula perbedaan karakteristiknya. Dalam proses pembelajaran PAI perbedaan karakteristik siswa ratarata dikarenakan latar belakang pendidikan siswa sebelum masuk ke SMA. Untuk mengatasi hal tersebut, guru PAI di SMA Negeri 1 Lamongan menciptakan pembelajaran yang dapat mengembangtumbukan kreativitas anak dengan memberikan motivasi dan bimbingan agar anak bisa menyesuaikan karakteristik dari masing-masing siswa, bisa mengikuti pembelajaran dengan baik, mampu memiliki mental yang pemberani dalam mengikuti proses pembelajaran PAI, mampu menghadapi tantangan zaman, dan mampu aktif, kreatif, dan inovatif dalam menerima dan mempelajari pembelajaran PAI di era revolusi industri 4.0. 
2. Metode Pembelajaran PAI

Dalam mengembangkan metode pembelajaran, ada tiga jenis variabel yang perlu diperhatikan, yaitu strategi pengorganisasian, strategi penyampaian, dan strategi pengelolaan pembelajaran.

\section{a. Strategi Pengorganisasian}

Dalam mengorganisasikan pembelajaran PAI, guru PAI SMA Negeri 1 Lamongan menyesuaikan dengan kurikulum, silabus, dan RPP yang sudah ditetapkan oleh pemerintah dan menyesuaikan dengan karakteristik siswa yang ada di SMA Negeri 1 Lamongan.

Materi-materi yang diajarkan mengacu pada buku paket pembelajaran PAI dan juga memperhatikan perkembangan pendidikan di era revolusi induatri 4.0 dengan memanfaatkan internet untuk mencari materi ataupun refrensi lain yang disesuaikan dengan materi yang diajarkan. Dalam hal ini siswa dilatih untuk mencari, mengerjakan, dan mampu mempertanggungjawabkan pekerjaannya baik secara individu ataupun kelompok yang bertujuan agar siswa bisa mengetahui informasi tentang materi tersebut sesuai dengan perkembangan zaman.

\section{b. Strategi Penyampaian}

Dalam strategi penyampaian guru PAI di SMA Negeri 1 Lamongan menggunakan berbagai macam metode pembelajaran dan menggunakan media pembelajaran sebagai penunjang keberhasilan guru dalam menyampaikan materi pembelajaran. Metode yang digunakan guru dalam penyampaian materi PAI di SMA Negeri 1 Lamongan adalah metode ceramah, diskusi, Tanya jawab, pemberian tugas, dan demonstrasi. Penggunaan metode tersebut disesuaikan dengan materi-materi yang dipelajari yang dapat memberikan pengaruh kepada peserta didik untuk memiliki daya tarik pada pembelajaran yang diajarkan.

Selain metode, ada media guru yang mendukung dalam penyampaian materi. Media pembelajaran yang tersedia di SMA Negeri 1 Lamongan sangat beragam semua media tersebut berguna untuk memberikan kemudahan kepada siswa dalam memahami materi pembelajaran. Dalam menghadapi era serba digital ini guru PAI di SMA Negeri 1 Lamongan memanfaatkan internet dalam proses pembelajaran PAI dengan menyesuaikan waktu dan materi tertentu, seperti menggunakan internet untuk mencari materi pembelajaran yang tidak ada dalam buku pelajaran, materi yang belum difahami, maupun mencari materi-materi yang terkini atau up to date. Semua penggunaan internet tersebut sebagai penunjang siswa untuk berhasil dalam mempelajari pembelajaran PAI dengan baik dan sesuai dengan perencanaan dan tujuan yang ingin dicapai.

Selain adanya metode dan media yang mendukung Guru PAI di SMA Negeri 1 Lamongan dalam menyampaiakan materi pelajaran, guru PAI melakukan usahausaha untuk mendukung dalam penyampaian materi pembelajaran, yaitu dengan cara selalu ikut dalam seminar-seminar, diklat dan workshop yang terkait dengan pembelajaran PAI, Melalui FGEP yang diselenggarakan melalui kemenag atau 
sekolah bisa membuat sendiri atau mandiri, dan dengan mengup to date pembelajaran PAI. Semua hal tersebut digunakan guru PAI untuk meningkatkan pengetahuan dan kreatifitas guru dalam penyampaian materi pembelajaran agar tidak didahului oleh peserta didik yang di era sekarang mereka bisa mendapatkan berbagai informasi melalui berbagai sumber apa saja berkat perkembangan teknologi yang semakin pesat di era revolusi industri 4.0 ini.

\section{c. Strategi Pengelolaan}

Dalam mengelola pembelajaran, guru PAI mengelola kondisi kelas supaya bisa belajar sesuai dengan tujuan pembelajaran yang ingin dicapai. Guru PAI di SMA Negeri 1 Lamongan memiliki cara dalam mengelola pembelajaran dengan memberikan kemudahan, memberikan motivasi dan mengajak siswa belajar di luar ruangan kelas, seperti di ruangan terbuka, masjid, dan perpus yang bertujuan agar siswa tidak bosan belajar di dalam kelas dan lebih semangat lagi dalam mempelajari pembelajaran PAI.

Guru PAI di SMA Negeri 1 Lamongan dalam mengelolah dan memberikan materi pembelajaran sudah memahami betul bahwa siswa di SMA Negeri 1 Lamongan sudah melek teknologi akibat canggihnya teknologi yang sudah berkembang. Oleh karena itu yang terpenting bagi guru PAI di era revolusi industri 4.0 bukan dari siswa dalam mendapatkan materi pelajaran melainkan cara dan sikap dalam mendapatkan materi tersebut, yaitu dengan mampu bersikap jujur dalam mengerjakan tugas-tugas yang diberikan oleh guru. karena hal tersebut dapat menyiapkan peserta didik mampu memiliki kemampuan berpikir kritis, kreatif, inovatif, dan memiliki karakter dan moral yang baik sebagai penunjang dalam kehidupan sehari-harinya.

\section{Hasil Pembelajaran PAI Berwawasan Lingkungan di Era Revolusi Industri 4.0}

Hasil pembelajaran PAI mencakup semua akibat yang dapat dijadikan indikator tentang nilai dari penggunaan metode pembelajaran PAI di bawah kondisi pembelajaran yang berbeda. Hasil pembelajaran dapat diklasifikasikan menjadi keefektifan, efesiensi, dan daya tarik.

1. Keefektifan Pembelajaran

Dalam mencapai hasil pembelajaran PAI yang optimal guru PAI di SMA Negeri 1 Lamongan memiliki berbagai cara dalam mengukur tingkat keefektifan peserta didik dalam mengikuti pembelajaran PAI, yaitu dengan cara :

a. Diukur berdasarkan kedisiplinan siswa lewat absensi

b. Diukur dengan pencapaian siswa dalam menjawab pertanyaan yang di berikan guru maupun kemampuan siswa dalam berdiskusi di dalam kelas.

c. Diukur dengan semangat siswa dalam mengerjakan tugas yang diberikan guru baik tugas individu maupun tugas kelompok

d. Diukur dengan perolehan penilaian siswa berdasarkan aspek kognitif, afektif, dan psikomotorik

e. Diukur dari hasil ulangan harian, UTS, maupun UAS 
f. Diukur dari nilai hafalan siswa baik pada kelancaran dan semangat siswa dalam menghafal

g. Diukur dari tingkah laku siswa baik pada teman, guru, maupun pada lingkungan sekitar, dari keaktifan siswa dalam melaksanakan sholat 5 waktu, dan dari sifat jujur yang dimiliki siswa dalam mengerjakan tugas-tugas yang diberikan.

Dari berbagai cara tersebut terbukti pembelajaran PAI di SMA Negeri 1 Lamongan sudah efektif sehingga membuat siswa lebih disiplin, semangat, dan efektif lagi dalam mengikuti dan mempelajari pembelajaran PAI. Dan guru PAI di SMA Negeri 1 Lamongan dalam mengukur keefektfan siswa tidak hanya dari aspek kognitifnya saja melainkan dari keaktifan sholat 5 waktu siswa dan karakter siswa untuk bisa bersikap jujur dalam menjawab soal-soal sesuai dengan pengetahuan yang mereka miliki, karena di era serba digital informasi bisa dicari melalui sumber apa saja, maka penting bagi seorang pendidik di era revolusi industri 4.0 dapat membentuk siswanya menjadi agen of change yang dapat mengikuti dan mengubah zaman menjadi lebih baik.

1) Efisiensi Pembelajaran

Dalam mengukur efesiensi pembelajaran guru PAI SMA Negeri 1 Lamongan mengacu pada jumlah waktu yang dibutuhkan oleh siswa untuk mencapai tujuan pembelajaran yang ditetapkan. Di SMA Negeri 1 Lamongan waktu pembelajaran yang digunakan sudah ditentukan seefisien mungkin dalam waktu 3 jam pembelajaran, waktu tersebut digunakan untuk pembelajaran, latihan-latihan soal, mengerjakan tugas-tugas yang ada, saling mencurahkan kesulitan atau hambatanhambatan yang dialami oleh siswa.

Berdasarkan hal tersebut guru PAI di SMA Negeri 1 Lamongan sudah efektif dalam mengefesiensi pembelajaran dengan mengadakan evaluasi sebagai tolak ukur dalam menilai sejauh mana pembelajaran yang sudah dilaksanakan. Dalam mengevaluasi pembelajaran guru PAI di SMA Negeri 1 Lamongan mengacu pada KKM (kriteria ketuntasan minimal) melalui penilaian tes dan non tes, melalui tiga spek kemampuan siswa yaitu pengetahuan, keterampilan dan sikap, melalui pertanyaan yang diajukan guru kepada siswa, dan dari hasil kerja siswa baik melalui tugas individu maupun kelompok.

2) Daya Tarik Pembelajaran

Daya tarik pembelajaran di SMA Negeri 1 Lamongan pada pembelajaran PAI tergantung pada daya tarik siswa dalam mengikuti dan mempelajari materi yang diajarkan dan dari cara guru dalam mengelola dan menyampaikan materi pembelajaran.

Dalam memunculkan daya tarik siswa pada proses pembelajaran guru PAI di SMA Negeri 1 Lamongan memiliki cara dengan membolak-balik metode pembelajaran yang digunakan yang disesuaikan dengan kondisi siswa, menggunakan media pembelajaran yang sudah ada di sekolah, dan memiliki inovasi dan kratifitas dalam mengorganisasikan dan menyampaikan materi untuk bisa mencapai hasil yang diharapkan dengan memanfaatkan perkembangan teknologi yang berkembang di era sekarang seperti menggunakan internet untuk mencari informasi-informasi yang tidak ada di buku dan informasi yang belum diketahui 
siswa, hal tersebut bertujuan untuk mencetak siswa yang siap dalam menghadapi tantangan di masa depan.

\section{Analisis tentang Faktor Pendukung dan Penghambat Pengembangan Pembelajaran PAI Sekolah Adiwiyata dalam Menghadapi Era Revolusi Industri di SMA Negeri 1 Lamongan}

Keberhasilan suatu bentuk kegiatan tidak lepas dari beberapa faktor pendukungdan penghambat. Adanya faktor pendukung membuat kegiatan semakin terlaksana menjadi lebih baik sedangkan adanya faktor penghambat membuat kegiatan menjadi kurang terlaksana secara maksimal.

1. Faktor Pendukung

Faktor pendukung dalam pengembangan pembelajaran PAI di era revolusi industri 4.0 di SMA Negeri 1 Lamongan, yaitu:

a. Latar belakang pendidikan siswa sebelum masuk ke SMA Negeri 1 Lamongan seperti dari pondok pesantren ataupun sekolah agama.

b. Adanya kegitan ekstrakulikuler KSI (Kelompok Studi Islam) yang di dalamnya ada kajian-kajian keislaman yang berkaitan dengan materi-materi pembelajaran PAI.

c. Adanya pembiasaan-pembiasaan program keagamaan yang sudah dijadwalkan dengan baik. Seperti sholat dhuha, pembiasaan membaca surat-surat pendek sebelum KBM, mengeluarkan infaq setiap hari jum'at, khotmil qur'an setiap satu bulan sekali, kajian rutin setiap satu bulan sekali, dan memperingati hari besar Islam.

d. Adanya sarana prasarana yang ada disekolah, seperti masjid, perpustakaan, maupun alat-alat peraga yang dapat digunakan siswa untuk kegiatan praktek.

e. Cara guru dalam menyampaikan pembelajaran yang dapat menarik perhatian siswa dengan memberikan semangat dan motivasi untuk bisa mengikuti pembelajaran PAI dengan baik.

f. Materi yang diajarkan oleh guru PAI menarik karena diumpamakan ke dalam kehidupan sehari-hari jadi siswa bisa mudah memahami.

g. Dari dalam diri siswa seperti kemampuan dan semangat siswa dalam mempelajari dan menerima materi pembelajaran PAI.

Dari beberapa faktor pendukung tersebut terbukti bisa membuat siswa di SMA Negeri1 Lamongan untuk lebih mudah dan semangat dalam memepelajari pembelajaran PAI, semua hal tersebut juga diimbangi dengan dukungan dan kreatifitas dalam menngelola pembelajaaran dari guru PAI untuk menunjang keberhasilan siswa dalam proses belajar mengajar PAI.

\section{Faktor Penghambat}

Selain adanya faktor pendukung di atas, dalam pengembangan pembelajaran PAI di era revolusi industri 4.0 di SMA Negeri 1 Lamongan ini juga memiliki faktor-faktor penghambat, yaitu:

a. Latar belakang siswa dari sekolah-sekolah umum yang masih sulit dalam memahami pembelajaran PAI karena kurangnya pengetahuan keagamaan, seperti 
siswa sulit dalam memahami dan meenafsirkan ayat-ayat Al Qur'an dan belum mengetahui hadist-hadist yang dipelajari siswa.

b. Dukungan dari keluarga yang tidak optimal dalam mengikutsertakan anaknya untuk mengikuti kegiatan-kegiatan keagamaan yang ada di lingkungan masyarakat seperti tidak mengikutkan anak pada majlis-majlis yang ada di rumah, sehingga berpengaruh pada kurangnya motivasi siswa dalam mengikuti kegiatan-kegiatan keagamaan di sekolah.

c. Terlalu dimanja oleh orangtua yang mengakibatkan siswa seenaknya sendiri dan berani kepada guru.

d. Materi PAI yang diajarkan tidak sedetail mungkin dikarenakan waktu pembelajaran yang digunakan hanya 3 jam dalam satu minggu yang mengakibatkan sulit dalam memahami materi.

e. Munculnya rasa malas, ngantuk pada siswa saat pembelajaran dan ramainya siswa saat materi pembelajaran berlangsung.

Dari pernyataan diatas, peneliti mengemukakan pendapat, bahwa dengan faktor pendukung sangat berpengaruh untuk jalannya suatu proses pembelajaran PAI yang berguna untuk mengembangkan pembelajaran PAI dengan baik dan dapat disesuaikan dengan perkembangan zaman untuk menyongsong era revolusi industri 4.0.

Sedangkan faktor penghambat kebanyakan terdapat dari dalam siswa sendiri. Untuk itu dengan segala hambatan yang ada bukanlah penghalang bagi guru PAI untuk tidak semangat dalam mengembangkan pembelajaran PAI kepada peserta didik. Melainkan dengan adanya faktor hambatan ini guru PAI di SMA Negeri 1 Lamongan mampu mengembangkan pembelajaran PAI yang lebih baik lagi dan bisa memberikan materi yang up to date atau bisa mengikuti perkembangan zaman di era revolusndustri 4.0. Dan mampu mencetak peserta didik untuk bisa memiliki kemampuan dan keterampilan dalam berfikir yang kreatif, kritis dan inovatif, dan mampu menyelesaikan masalah di era revolusi industri 4.0.

\section{Strategi Alternatif Pengembangan Pembelajaran Pendidikan Agama Islam Sekolah Adiwiyata dalam Menghadapi Era Revolusi Industri 4.0}

Dalam sebuah permasalahan pasti akan ada upaya untuk mengatasi masalah tersebut. Berdasarkan beberapa faktor pengambat yang telah disebutkan di atas mengenai pengembangan pembelajaran PAI di era revolusi industri 4.0, maka perlu diminimalisir dan dicari solusinya, yaitu dengan:

1. Memberikan bimbingan dan arahan kepada siswa dalam menyelesaikan kesulitan dan masalah-masalah yang dihadapi dalam proses pembelajaran.

2. Memberikan motivasi maupun dorongan untuk membangkitkan semangat siswa baik dalam mengikuti pembelajaran PAI maupun kegiatan keagamaan sekolah.

3. Melakukan kerjasama antara antara siswa, guru, dan orang tua dengan mengatasi hambatan-hambatan yang dihadapi siswa di sekolah untuk menunjang keberhasilan pendidikan siswa. 
4. Pihak sekolah mengadakan ekstrakulikuler baca tulis Al Qur'an dan kajian studi Islam untuk menunjang pemahaman siswa pada pembelajaran PAI karena terbatasnya jam pelajaran PAI hanya 3 jam pelajaran dalam satu minggu.

5. Dalam pembelajaran guru memberikan arahan, semangat dan gurauan kepada siswa untuk membangkitkan semangat dan minat siswa dalam mengikuti pembelajaran PAI.

Seorang guru dalam pendidikan dituntut untuk komitmen terhadap profesionalisme, seorang guru dikatakan professional bilamana pada dirinya melekat sikap dedikatif yang tinggi terhadap tugasnya, memiliki sikap komitmen terhadap mutu proses dan hasil kerja, serta selalu memperbaiki dan menyelesaikan masalah-masalah yang dihadapi siswa sesuai dengan tuntutan zaman. Semua itu dilandasi oleh kesadaran tinggi bahwa tugas mendidik adalah tugas menyiapkan generasi penerus yang akan hidup pada masa zamannya.

Agar pengembangan pembelajaran PAI berjalan dengan baik, maka guru PAI melakukan kerjasama antara keluarga, siswa, dan guru. karena elemen tersebut memiliki kontribusi penting untuk mendukung pendidikan anak dan keberhasilan pendidikan anak adalah tanggungjawab bersama.

Terutama di kehidupan sekarang sudah memasuki era revolusi industri 4.0, di mana di era ini guru dituntut untuk menyiapkan peserta didik yang bisa mengikuti perkembangan zaman dalam proses belajar mengajar dengan cara melatih siswa bisa mandiri dalam belajar, mengarahkan pada pembelajaran yang up to date, siswa bisa siap, sigap, dalam menghadapi situasi dan kondisi yang dihadapi, dan siswa mampu memiliki kepribadian, karakter, dan moral yang baik. Karena semua hal tersebut yang dapat membuat diri siswa mampu memiliki kemampuan dan keterampilan dalam berfikir yang kreatif, kritis dan inovatif, mampu menyelesaikan masalah, mampu bekerja sama, dan mampu menghadapai tantangan perekembangan zaman di era revolusi industri 4.0 ini.

\section{Kesimpulan}

Berdasarkan hasil penelitian dalam skripsi ini, terkait dengan Pengembangan Pembelajaran Pendidikan Agama Islam Sekolah Adiwiyata dalam Menghadapi Era Revolusi Industri di SMA Negeri 1 Lamongan, dapat ditarik kesimpulan sebagai berikut: pertama, Pengembangan Pembelajaran Pendidikan Agama Islam Sekolah Adiwiyata dalam Menghadapi Era Revolusi Industri di SMA Negeri 1 Lamongan adalah dengan memperhatikan komponen-komponen yang mempengaruhinya, yaitu: 1) Kondisi Pembelajaran; 2) Metode Pembelajaran PAI, dan 3) Hasil Pembelajaran PAI, yang meliputi a) Keefektifan Pembelajaran.

Strategi alternatif yang bisa diadopsi dalam problem yang muncul dalam pengembangan Pembelajaran Pendidikan Agama Islam Sekolah Adiwiyata di Era Revolusi Industri 4.0, yaitu dengan memberikan bimbingan dan arahan kepada siswa dalam menyelesaikan kesulitan dan masalah-masalah yang dihadapi dalam proses pembelajaran melalui platform digital, Memberikan motivasi maupun dorongan untuk membangkitkan semangat siswa, melakukan kerjasama antara antara siswa, guru, dan 
orang tua, pihak sekolah mengadakan ekstrakulikuler baca tulis Al Qur'an dan kajian studi Islam untuk menunjang pemahaman siswa pada pembelajaran, dalam pembelajaran guru memberikan arahan, semangat dan gurauan kepada siswa untuk membangkitkan semangat dan minat siswa dalam mengikuti pembelajaran PAI.

\section{Daftar Rujukan}

Albab, Hayyan Ahmad Ulul. "Memahami PAI melalui Program Adiwiyata (Cinta Lingkungan) di SMPN 2 Lamongan", Jurnal JALIE, No.2, Vol.1, September, 2017.

Baharuddin. Pendidikan dan Psikologi Perkembangan. Yogyakarta : Ar-Ruzz Media, 2017.

Departemen Agama RI, Al-Qur'an dan Terjemahnya, Bandung: CV Penerbit Jumanatul AliArt, 2004

Hair, Afiful. "Pendidikan Islam dalam Fenomena Disruption 4.0", Jurnal Pemikiran, Pendidikan, dan Penelitian Keislaman, No.2, Vol.05, Juli, 2019.

Ilyasin, Mukammad dan Nanik Nur Hayati, Manajemen Pendidikan Islam.Yogyakarta : Aditya Media Publishing, 2012.

Muhaimin, Paradigma Pendidikan Islam: Upaya Mengefektifkan Pendidikan Agama Islam di Sekolah, Bandung: PT Remaja Rosdakarya, 2008

Safitri, Astrid. Revolusi Industri 4.0 : Mengubah Tantangan Menjadi Peluang di Era Disrupsi 4.0. Yogyakarta : Penerbit Genesis, 2019.

Widaningsih, Ida. Strategi dan Inovasi Pembelajaran Baasa Indonesia di Era Revolusi Industri 4.0. Ponorogo : Uwais Inspirasi Indonesia, 2019.

Al-Qur'an, 3: 190. 